\title{
Lingkungan Kewirausahaan dalam Motivasi Berwirausaha
}

\author{
R.A. Tammie ${ }^{1}$, B.L. Nuryanti \& R.D.H. Utama \\ Universitas Pendidikan Indonesia \\ riekeamaluthviet@upi.edu
}

\begin{abstract}
This study aims to determine the effect of entrepreneurial environment to entrepreneurial motivation. This research uses descriptive approach with explanatory survey method. The student analysis unit is 167 people. Data collection using questionnaire. The analysis technique used is verifikative technique by using frequency distribution. The result showed that entrepreneurial environment enough effected on entrepreneurial motivation. The differences in this study located on an object research, time research, a measuring instrument, literature that used, the theory that is used and the results of the study
\end{abstract}

Keywords: entrepreneurial envriontmen; entrepreneurial motivation

Abstrak. Penelitian ini bertujuan untuk mengetahui seberapa besar pengaruh lingkungan kewirausahaan terhadap motivasi berwirausaha. Penelitian ini menggunakan pendekatan verifikatif dengan metode explanatory survey. Unit analisis siswa sebanyak 167 orang. Pengumpulan data dengan menggunakan kuesioner. Teknik analisis yang digunakan adalah teknik verifikatif dengan menggunakan distribusi frekuensi. Hasil penelitian menunjukan lingkungan kewirausahaan memiliki pengaruh cukup terhadap motivasi berwirausaha.

Kata Kunci: lingkungan kewirausahaan; motivasi berwirausaha

\section{PENDAHULUAN}

Pendidikan kewirausahaan telah lama dijadikan sebagai salah satu pilar ekonomi dalam menghadapi perubahan ekonomi dan sosial oleh pemerintah Indonesia . Tingginya motivasi seseorang dalam berwirausaha mendorong jumlah wirausaha di Indonesia. Salah satu kunci determinasi keberhasilan usaha adalah motivasi berwirausaha (Eijdenberg, 2016). Pengambilan resiko dan ketertarikan untuk mencapai keberhasilan usaha merupakan fokus motivasi berwirausaha (Ismail, Husin, Abdul, Hanum, \& Che, 2016). Penelitian di berbagai bidang telah menunjukan bagaimana motivasi seseorang untuk memulai berwirausaha (Knight, 2015). Penelitian tentang motivasi berwirausaha penting untuk diteliti untuk mengetahui motivasi dan perilaku membantu memahami bagaimana mereka melaksanakan kegiatan sehari-hari dan sesuai dengan lingkungan, serta memahami bagaimana mereka memprediksi kemajuan bisnis berskala kecil mikro dan menengah (Eijdenberg, 2016).

\begin{abstract}
Salah satu permasalahan dalam kewirausahaan adalah rendahnya motivasi berwirausaha. Permasalahan motivasi berwirausaha jika diabaikan akan menyebabkan penurunan jumlah wirausaha disuatu negara (Dehkordi, Sasani, Candidate, \& Management, 2012). Mengembangkan perilaku kewirausahaan diperlukan proses yaitu identifikasi sifat-sifat yang berhubungan dengan kewirausahaan (Mulyadi \& Irawan, 2016). Rendahnya motivasi seorang siswa SMK untuk berwirausaha, maka menjadikan rendahnya wirausaha yang terbentuk setelah siswa menyelesaikan jenjang pendidikannya. Hal ini tentu dipengaruhi bagaimana proses belajar mengajar disekolah. Metode pembelajaran telah dikembangkan untuk meningkatkan hasil belajar peserta didik, baik berupa perubahan sikap, bertambahnya ilmu, dll (Fayolle, Boluk \& Mottiar, Sastradinata, Yao)

Penelitian tentang tingkat motivasi berwirausaha telah dilakukan oleh banyak peneliti. Permasalahan tingkat motivasi berwirausaha menjadi gagasan dalam penelitian baik di dalam bidang pendidikan maupun ilmu praktis (Boluk \&
\end{abstract}


Mottiar, 2014). Memahamai faktor sikap yang mendukung motivasi berwirausaha dan memfasilitasi siswa dalam berwirausaha mendorong siswa untuk berwirausaha (Dehkordi et al., 2012). Penelitian menunjukan pembelajaran kewirausahaan tidak menunjukan peningkatan motivasi siswa dalam berwirausaha. Mengingat beberapa penelitian mengatakan siswa yang mengikuti pelatihan yang didalamnya terdapat kurikulum kewirausahaan menunujukan kecenderungan dan motivasi untuk berwirausaha (Sarmento, 2016). Latihan dan pendidikan berpengaruh terhadap perilaku dan sikap kewiraushaaan mahasiswa di lingkungan pendidikan (Mulyadi, 2010)

Kegiatan akademik maupun non akademik dapat membangun motivasi berwirausaha pada siswa ( Orziemgbe et al., 2014). Pembelajaran kewirausahaan dapat mendorong siswa untuk lebih termotivasi untuk berwirausaha merupakan contoh kegiatan akademik adalah. Sekolah akan mampu menciptakan motivasi berwirausaha yang lahir dari diri siswa melalui pengembangan lingkungan kewirausahaan sehingga terbentuk motivasi yang lebih kuat dari pada motivasi yang terbentuk karna lingkungan atau faktor eksternal.

Model pembelajaran yang inovatif dan kreatif diharapkan dapat mengelola dan mengembangkan komponen pembelajaran dalam suatu desain yang terencana dengan memperhatikan kondisi aktual dari faktor-faktor penunjang dalam implementasi pembelajaran yang akan dilakukan. Untuk meningkatkan kreativitas dan minat belajar mahasiswa maka diperlukan fasilitas yang membantu untuk mengembangkan kemampuan kognitif siswa yaitu media pembelajaran (Nuryanti, 2004).

Peningkatan lingkungan kewirausahaan yang kondusif menjadi solusi yang efektif dalam meningktakan motivasi berwirausaha (Shetzer, Stackman, \& Moore, 2010). Penelitian yang dilakukan oleh Olvecka (2013) menyatakan bahwa lingkungan kewirausahaan berpengaruh positif dan signifikan terhadap motivasi berwirausaha, sedangkan penelitian yang dilakukan oleh Fereidouni, Masron, \& Nikbin (2010) menyatakan bahwa lingkungan kewirausahan kurang berpengaruh signifikan terhadap motivasi berwirausaha siswa.

Teori yang dikemukakan oleh Nafziger (2011) bahwa motivasi berwirausaha dipengaruhi oleh business environment. Lingkungan kewirausahaan berpengaruh pada perilaku dan karakteristik wirausaha seseorang. Berdasarkan teori tersebut maka faktor lingkungan kewirausahaan berpengaruh pada motivasi berwirausaha siswa. Siswa SMK yang memiliki lingkungan kewirausahaan yang kondusif cenderung akan lebih termotivasi untuk berwirausaha.

Berdasarkan latar belakang masalah di atas, maka tujuan penelitian ini adalah untuk memperoleh hasil temuan mengenai: (1) gambaran lingkungan kewirausahaan dan (2) motivasi berwirausaha.

Lingkungan kewirausahaan merupakan kombinasi dari beberapa faktor yang memainkan peran dalam membangun kewirausahaan (Fereidouni et al., 2010) Lingkungan kewirausahaan merupakan gabungan dari beberapa faktor yang menyebabkan terjadinya proses kewirausahaan yang dapat membentuk wirausaha (Koranti, 2013)

Keinginan untuk penciptaan kekayaan merupakan pendorong yang signifikan. Faktor ini diasumsikan tergantung pada lingkungan yang diberikan. Misalnya. Pajak pendapatan kewiraswastaan, keuntungan modal dan dividen bervariasi di berbagai lingkungan, negara bagian dan negara. Oleh karena itu ekspektasi finansial juga bisa dikaitkan dengan atribut lingkungan.Kemunculan peluang dan pengakuan telah ditemukan sebagai fenomena sentral dalam bidang kewirausahaan. Lingkungan dapat dikaitkan dengan kemunculan peluang dan persepsi peluang masing (Gnyawali \& Fogel, 2010) dan diasumsikan berbeda dari lingkungan ke lingkungan lainnya.

Lingkungan kewirausahaan terbagi menjadi 3 dimensi yaitu dimensi linkungan sosial, methods dan lingkungan kebijakan (Mitra, 2013). Programmes merupakan lingkungan yang dapat mempengaruhi seseoarang melalui jaringan interpersonal dan sosial budaya . Programmes meliputi orangtua, teman sekolah dan masyarakat. 
Programmes mendukung kepercayaan seseoranguntuk berwirausaha.

Methods merupakan situasi pembangunan dan kompetisi pasar yang ada. Lingkungan kebijakan maksudnya adalah kebijakan dan peraturan pemerintah seperti hukum dan undang-undang yang mendukung seseorang untuk berwirausaha. Pada penelitian ini kebijakan yang dimaksud adalah kebijakan sekolah dan orangtua dalam mendukung proses kewirausahaan siswa. Siswa yang memprolah dukungan dari sekolah dan orangtua akan merasa aman dan nyaman untuk berwirausaha.

Motivasi adalah kekuatan tersembunyi di dalam diri kita yang mendorong kita untuk berkelakuanj dan bertindak dengan cara yang khas (Basrowi, 2011). Motivasi merupakan proses psikologi yang mencerminkan interaksi sikap, kebutuhan, persepsi, dan keputusan yang terjadi pada diri seseorang Wahjosumidjo dalam Rusdiana (2014:70)

Dibawah ini beberapa motivasi berwirausaha menurut Djati Utomo (2007:31) .

1. Hasrat berprestasi (Need for Achievement/Nach). Seseorang yang kuat hasrat berprestasi tampakmya berpeluang besar untuk menjadu wirausaha sukses. Keinginan untuk mengerjakan sesuatu dengan lebih baik dimasa depan dibandingkan masa lalu.

2. Kemandirian, kesaling tergantungan dan nasib baik. Salah satu aspek kompetensi yang penting bagi seorang wirausaha ialah kemampuan untuk mewujudkan sesuatu. Seseorang dengan keyakinan kendali nternal (internal control), percaya bahwa sebagian besar kehidupan dan bisnisnya dikendalikan oleh dirinya sendiri. Dengan keyakinan besar bahwa hal-hal penting ada dibawah kontrolnya, seorang wirausaha wajib tahu kapan dan dengan siapa ia harus menerima dan membagi lntrol dalam hal-hal tertentu dengan pihak lain. Wirausaha mempercayai keberuntungan, peluang dan kesempatan.

3. Berani mengambil resiko. Secara umum wirausaha dapat menerima resiko yang timbul, dan ini cukup memadai dibandingkan hasil yang mereka kejar. Para wirausaha mengelola resiko antara lain melalui psikologis, misalnya menganggap ancaman halangan sebagai tantangan atau masalah peluang atau membicarakan bisnis dari sisi positifnya karena membicaraan sisi negative dapat melemahkan motivasi.

4. Pengalaman masa kecil. Kesulitan yang pernah mendera telah membuat banyak anak berikir kreatif dan inovatif untuk mengakali hidup.

5. Frustasi dengan karir organisasi. Sebagian besar banyak merasakan karirnya terhenti di posisi tertentu atau mengalami ketidakpastian kerja. Bagi orang-orang tertentu situasi ini tidak membuat mereka terhenti tetapi memberi motivasi untuk tetap berkarya dengan berwirausaha.

6. Panutan. Banyak wirausaha yang termotivasi berwirausaha karena melihat keberhasilan orang, idola atau panutan mereka misalnya orang lain, keluarha terdekat, tetangga atau tokoh bisnis yang berhasil.

Motivasi merupakan salah satu faktor keberhasilan wirausaha dalam menyelesaikan tugasnya. Semakin besar motivasi maka semakin besar kesuksesan yang dicapai. Faktor-faktor pendorong disebut juga faktor penyebab kepuasan. Adanya kepuasan akan menambah semangat untuk melaksanakan aktivitas (Herzberg dalam Rusdiana 2014:71).

Menurut Hoy dan Cecil dalam Rusdiana (2014:71) , motivasi utama manusia untuk melakukan kegiatan adalah harapan. Tiga faktor yang menentukan motivasi, yaitu:

1. Harapan, yaitu keinginan bahwa suatu usaha yang dilakukan pasti akan berhasil.

2. Valensi, yaitu tingkat ikatan, keikutsertaan batiniah seseorang terhadap suatu aktivitas.

3. Peralatan/kebutuhan, yaitu pendukung, alat, kemampuan yang dimiliki seseorang guna mencapai tujuan.

Menurut Basrowi (2011: 67-68), motivasi seseorang menjadi wirausaha, yaitu:

1. Laba. Seorang wirausaha dapat menetukan berapa laba yang dkehendaki dan keuntungan yang akan diperoleh serta berapa yang akan dibayarkan kepada pihak lain dan karyawannya.

2. Kebebasan. Bebas mengatur waktu, bebas dari aturan yang menekan dan bebas dari aturan budaya organisasi. 
3. Impian personal. Bebas mencapai standar hidup yang diinginkan, bebas dari rutinitas kerja yang membosankan. Imbalan untuk menentukan misi, visi dan impian sendiri.

4. Kemandirian. Memiliki rasa bangga, karena dapat mandiri dalam segala hal dengan usaha sendiri.

Menurut Jay Mitra (2012) mengemukakan motivasi berwirausaha dibagi menjadi beberapa dimensi yaitu :

1. Independence, adalah kemandirian. Seorang wirausaha ingin bisa membuat keputusan oleh dirinya sendiri. Seorang wirausaha tidak ingin bergantung dengan orang lain.

2. Self-Confidence, artinya percaya diri dibagi menjadi dua jenis yaitu percaya diri secara umum dan percaya diri secara khusus. Percaya diri secara umum yaitu seseorang yang percaya bahwa dirinya bisa menghadapi dunia, menghadapi tantangan, mengatasi hambatam dan percaya mampu mencapai impiannya. Sementara percaya diri khusus adalah kepercayaan dalam diri bahwa dirinya mampu mengatasi masalah secara khusus.

3. Achievement Motivation, maksudnya adalah motivasi berprestasi yaitu keinginan untuk mencapai prestasi standar yang cemerlang, misalnya untuk meningkatkan laba penghasilan, performa usaha, dll.

4. Drive to Action, yaitu arah untuk bertindak, seorang yang memiliki motivasi akan memiliki proactivity, ambisi, dan energi.

5. Egoistic Passion, yang dimaksud adalah egois dalam berwirausaha, yaitu keinginan untuk menang, berkuasa dan maju secara pribadi dalam berwirausaha.

6. Tenacity, artinya adalah keuletan, seorang yang memiliki motivasi berwirausaha akan cenderung ulet dalam bekerja dan berwirausaha.

Berdasarkan uraian beberapa ahli diatas maka pada penelitian ini peneliti mengambil dimensi motivasi berwirausaha menurut Fayolle (2017) yaitu . Independence, Striving for Achievement, Self realiation dan Ambition for Freedom.

Berdasarkan penjelasan mengenai gambaran lingkungan kewirausahaan dan motivasi berwirausaha, maka disusun sebuah paradigma analisis lingkungan kewirausahaan dan motivasi berwirausaha secara jelas digambarkan dalam Gambar 1 sebagai berikut:



Gambar 1. Paradigma Penelitian

\section{METODE PENELITIAN}

Metode penelitian yang digunakan dalam penelitian ini adalah penelitian verifikatif. Penelitian verifikatif dilakukan untuk mengetahui dan menjadi mampu untuk menjelaskan karakteristik variabel yang diteliti dalam suatu situasi (Sekaran, 2014). Penelitian verifikatif menurut Suharsimi Arikunto (2010:8) pada dasarnya ingin menguji kebenaran dari suatu hipotesis yang dilaksanakan melalui pengumpulan data di lapangan. Penelitian verifikatif memprediksi dan menjelaskan hubungan variabel satu dengan variabel lain. Dalam penelitian ini diuji mengenai pengaruh lingkungan kewirausahaan terhadap motivasi berwirausaha siswa kelas XII SMKN 1 Cimahi.

Berdasarkan jenis penelitian yaitu penelitian verifikatif maka metode yang digunakan dalam penelitian ini adalah explanatory survey yang bertujuan untuk mengetahui hubungan antar variabel dengan cara pengujian hipotesis. Metode explanatory survey adalah penelitian yang dilakukan untuk mengetahui sesuatu secara keseluruhan dari wilayah atau objek penelitian (Nasahudin 2012:56). Kesimpulan dari hasil penelitian tersebut berlaku umum (general) untuk seluruh informasi dari sebagian populasi dikumpulkan langsung ke tempat kejadian secara empirik dengan tujuan untuk mengetahui pendapat dari sebagian populasi terhadap objek yang diteliti

Jenis dan sumber data yang digunakan dalam penelitian ini dapat dilihat lebih jelas pada Tabel 1 sebagai berikut.

\section{Tabel 1. Jenis Dan Sumber Data}




\begin{tabular}{|c|c|c|c|}
\hline No. & Data & $\begin{array}{c}\text { Jenis } \\
\text { Data }\end{array}$ & $\begin{array}{c}\text { Sumber } \\
\text { Data }\end{array}$ \\
\hline 1 & $\begin{array}{l}\text { Data Siswa } \\
\text { SMK N } 1 \\
\text { Cimahi yang } \\
\text { Berwirausah } \\
\text { a }\end{array}$ & Primer & $\begin{array}{l}\text { Pra } \\
\text { penelitian } \\
\text { ke sekolah }\end{array}$ \\
\hline 2 & $\begin{array}{l}\text { Data } \\
\text { Gambaran } \\
\text { Motivasi } \\
\text { Berwirausah } \\
\text { a Siswa } \\
\text { Kelas XII } \\
\text { SMK N 1 } \\
\text { Cimahi }\end{array}$ & Primer & $\begin{array}{l}\text { Pra } \\
\text { penelitian } \\
\text { ke sekolah }\end{array}$ \\
\hline 3 & $\begin{array}{l}\text { Data } \\
\text { Gambaran } \\
\text { Lingkungan } \\
\text { Kewiraushaa } \\
\text { n Siswa } \\
\text { SMK N } 1 \\
\text { Cimahi }\end{array}$ & Primer & $\begin{array}{l}\text { Pra } \\
\text { Penelitian } \\
\text { ke sekolah }\end{array}$ \\
\hline
\end{tabular}

Sumber: Pra Penelitian 2018

Populasi yaitu kumpulan dari individu dengan kualitas serta ciri-ciri yang telah ditetapkan. Populasi merupakan sejumlah objek yang akan dijadikan sumber penelitian (Yang, Ju, \& Lee, 2016). Populasi adalah wilayah generalisasi yang terdiri atas objek atau subjek yang mempunyai kuantitas dan karakteristik tertentu yang ditetapkan oleh peneliti untuk dipelajari dan kemudian ditarik kesimpulannya (Sugiyono, 2014:115). Populasi merupakan objek yang lengkap dan jelas yang ingin dipelajari sifat-sifatnya serta merupakan keseluruhan elemen atau anggota dari suatu wilayah yang menjadi sasaran penelitian atau merupakan keseluruhan dari objek penelitian (Waqas et al., 2014). Pengambilan sampel diperkenankan mengambil sebagian dari objek populasi yang telah ditentukan, dengan catatan bagian yang diambil tersebut mewakili yang lain yang tidak diteliti (Sugiyono, 2014:150). Teknik penarikan sampel yang digunakan dalam penelitian ini adalah teknik penelitian populasi atau sensus, karena sampel diambil dari seluruh populasi yang dinamakan sampel jenuh.

Penelitian ini menggunakan teknik simply random sampling karena jumlah populasi lebih dari
600 orang, dan sample yang diambil adalah yaitu sebanyak 167 orang siswa. Populasi dalam penelitian ini adalah siswa kelas XII SMK Negeri 1 Cimahi yang berjumlah 676 orang. Teknik pengumpulan data yang digunakan adalah studi kepustakaan, studi lapangan dengan penyebaran kuesioner secara langsung, dan studi literatur. Teknik analisis data menggunakan distribusi frekuensi.

Penelitian verifikatif adalah penelitian yang bertujuan untuk menguji suatu teori atau hasil penelitian sebelumnya, sehingga diperoleh hasil yang memperkuat atau menggugurkan teori atau hasil penelitian tersebut.

\section{Asumsi Klasik \\ a. Uji Normalitas}

Uji normalitas dilakukan untuk melihat apakah data populasi memiliki distribusi normal atau tidak sehingga dapat dipakai dalam statistik parametrik. Adapun tujuan dari dilakukannya uji normalitas data adalah untuk mengetahui apakah suatu variabel normal atau tidak. Dalam pembahasan ini akan digunakan uji Liliefors dengan melihat nilai Kolmogorov-Smirnov. Data dinyatakan berdistribusi normal jika signifikasi lebih besar dari 0,05 dengan rumus sebagai berikut

\begin{tabular}{|l|l|l|l|l|l|}
\hline$N_{0}$ & $\mathrm{X}_{\mathrm{i}}$ & $\mathrm{Z}=\frac{X_{i}-\bar{X}}{S D}$ & $\mathrm{~F}_{\mathrm{T}}$ & $\mathrm{FS}_{\mathrm{S}}$ & $\left|\mathrm{FT} \cdot \mathrm{F}_{\mathrm{S}}\right|$ \\
\hline
\end{tabular}

Keterangan :

$\mathrm{XII}=$ Angka pada data

$\mathrm{Z}=$ Transformasi dari angka ke notasi pada distribusi normal

FT $=$ Probabilitas komulatif normal

FS = Probabilitas komulatif empiris.

\section{b. Uji Linearitas}

Uji linieritas dilakukan untuk mengetahui bahwa variabel-variabel yang dirumuskan dalam model teoritik penelitian mempunyai hubungan yang linier. Jika ada hubungan antara dua variabel yang belum diketahui apakah linear atau tidak, uji linearitas tidak dapat digunakan untuk memberikan adjustment bahwa hubungan tersebut bersifat linear atau tidak. Uji linearitas digunakan untuk mengkonfirmasikan apakah sifat linear antara dua variabel yang diidentifikasikan secara teori sesuai atau tidak dengan hasil observasi yang ada. Uji 
linearitas dapat menggunakan uji Durbin-Watson, Ramsey Test atau uji Lagrange MultiplierC. Uji Heterokedastisitas

Untuk menerapkan uji Ramsey Test ada beberapa langkah yang harus ditempuh yaitu :

1) Lakukan estimasi dengan menggunakan persamaan berikut :

$\mathrm{Y}_{\mathrm{t}}=\mathrm{a}_{0}+\mathrm{a}_{1} \mathrm{X}_{1 \mathrm{t}}+\mathrm{a}_{2} \mathrm{X}_{2 \mathrm{t}}+\mathrm{a}_{3} \mathrm{~F}_{\mathrm{yt}}{ }^{2}+\mathrm{u}_{\mathrm{t}}$

2) Lakukan regresi dengan memasukkan nilai fitted $\mathrm{Yt}, \quad \mathrm{F}_{\mathrm{yt}}$ sebagai variabel tambahan variabel bebas dengan model persamaan regresinya sebagai berikut :

$\mathrm{Y}_{\mathrm{t}}=\mathrm{a}_{0}+\mathrm{a}_{1} \mathrm{X}_{1 \mathrm{t}}+\mathrm{a}_{2} \mathrm{X}_{2 \mathrm{t}}+\mathrm{a}_{3} \mathrm{~F}_{\mathrm{yt}}{ }^{2}+\mathrm{u}_{\mathrm{t}}$

Dimana FYR $\mathrm{R}_{\mathrm{t}}$ adalah nilai fitted dari $\mathrm{Y}_{\mathrm{t}}$

3) Dapatkan nilai $r^{2}$ dari persamaan

4) yang selanjutnya diberi nama dengan $r^{2}{ }_{\text {new }}$ dan dapatkan nilai $r^{2}$ dari persamaan (1) yang selanjutnya diberi nama $r^{2}$ old. Setelah nilai $r^{2}$ kedua persamaan tersebut ditemukan kemudian hitunglah nilai $\mathrm{F}_{\text {hitung }}$ atau $\mathrm{F}_{\text {tes }}$ dengan rumus berikut :

$$
F=\frac{\left(R_{n e w}^{2}-R_{o l d}^{2}\right) / m}{\left(1-R_{n e w}^{2}\right) /(n-k)}
$$

dimana

$\mathrm{m}=$ jumlah variabel bebas yang baru masuk

$\mathrm{n}=$ jumlah data/observasi

$\mathrm{k}=$ banyaknya parameter dalam persamaan baru

Dari hasil perhitungan nilai $F_{\text {hitung }}$ dengan menggunakan persamaan diatas kemudian bandingkan nilai $F_{\text {hitung }}$ dengan nilai $F_{\text {tabel }}$ dengan pedoman bila nilai $F_{\text {hitung }}>$ nilai $F_{\text {tabel, maka }}$ hipotesis nol $\left(\mathrm{H}_{\mathrm{o}}\right)$ yang menyatakan bahwa spesifikasi model digunakan dalam bentuk fungsi linier adalah benar ditolak dan sebaliknya, bila nilai $\mathrm{F}_{\text {hitung }}<$ nilai $\mathrm{F}_{\text {tabel }}$ maka hipoptesis $\mathrm{H}_{\mathrm{o}}$ yang menyatakan bahwa spesifikasi model digunakan dalam bentuk fungsi linier adalah benar tidak dapat ditolak

\section{c. Diagram Pencar}

Diagram pencar adalah gambaran yang menunjukan kemungkinan hubungan (korelasi) antara pasangan dua macam variabel. Menurut Siagian \& Sugiarto (2006:225) mengatakan bahwa diagram pencar untuk memberikan gambaran hubungan dua variabel, sebelum mengetahui apakah berhubungan linear atau tidak sebaiknya dilakukan plotting (tebaran titik) terhadap pasangan nilai-nilai X dan Y. Diagram pencar menunjukan gambar secara kasar bahwa pola hubungan variabel terikat atas variabel bebas adalah pola hubungan yang linear maka, dapat dijadikan alasan bahwa model hubungan ini adalah model regresi linear sederhana yaitu, $y=a+b X$

\section{Positive Correlation Negative Correlation}

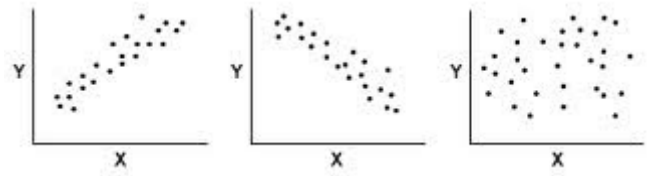

No Correlation

Sumber: Sekaran (2014)

\section{Gambar 2.Model Diagram Pencar}

Gambar 2 menunjukan model dari diagram pancar, jika titik-titik penyebaran berada pada arah kiri bawah ke kanan atas maka hubungan antara variabel bebas dan variabel terikat adalah positif, jika titik-titik penyebaran ada pada kiri atas ke kanan bawah maka hubungan variabel bebas dan variabel terikat adalah negatif, dan jika titik-titik penyebaran berada pada posisi sembarangan maka tidak ada hubungan antara variabel bebas dan variabel terikat.

\section{d. Uji Titik Terjauh}

Setelah diketahui model diagram pencar dan telah menunjukkan pola garis lurus atau linear, langkah selanjunya adalah memperlihatkan titiktitik yang letaknya terpencil pada diagram pencar. Titik yang ditemukan pada diagram pencar peru diuji apakah titik tersebut merupakan titik terpencil atau tidak, jika merupakan titik terpencil maka titik tersebut harus dikeluarkan dari analisis. Guna mengeluarkan titik terpencil, dapat menggunakan test for outlier in regression analysis dengan perumusan hipotesis sebagai berikut:

$\mathrm{H}_{\mathrm{o}} \quad$ : Titik tersebut bukan merupakan titik terpencil

$\mathrm{H}_{1} \quad$ : Titik tersebut merupakan titik terpencil Uji statistik yang digunakan yaitu mengacu pada formula Nirwana SK Sitepu (1994:19):

$$
t=\frac{Y-\tilde{Y}}{S_{Y}-\tilde{Y}}
$$


(Nirwana SK Sitepu, 1994:19)

Keterangan :

$\hat{Y}$ : Variabel dependen atau nilai variabel yang diperdiksikan

Y : Skor nilai variabel dependen

$S_{Y}:$ Standar error untuk Y

Kriteria yang digunakan dalam uji ini adalah sebagai berikut :

$\mathrm{t}>\mathrm{t}_{\mathrm{n}-2}$ : Tolak $\mathrm{H}_{\mathrm{o}}$, artinya titik yang mencurigakan dianggap sebagai titik terpencil dan harus dikeluarkan dari analisis

$\mathrm{t} \leq \mathrm{t}_{\mathrm{n}-2}$ : Terima $\mathrm{H}_{\mathrm{a}}$, artinya titik yang mencurigakan tidak dianggap sebagai titik

terpencil dan tidak perlu dikeluarkan dari analisis.

Setelah melakukan perhitungan dan telah diketahui nilai untuk a dan $b$, kemudian nilai tersebut dimasukkan kedalam persamaan regresi sederhana untuk mengetahui perubahan yang terjadi pada variabel $\mathrm{Y}$ berdasarkan nilai variabel $\mathrm{X}$ yang diketahui. Persamaan regresi tersebut bermanfaat untuk meramalkan rata-rata variabel $Y$ dan $\mathrm{X}$ diketahui dan memperkirakan rata-rata perubahan variabel Y untuk setiap perubahan X.

\section{Regresi Linear Sederhana}

Analisis regresi linear sederhana adalah hubungan secara linear antara satu variabel independent $(\mathrm{X})$ dan satu variabel dependent $(\mathrm{Y})$ namun sebelum kita mencari hubungan secara linear kita menganalisis korelasinya terlebih dahulu. Analisis korelasi parsial ini digunakan untuk mengetahui kekuatan hubungan anatara korelasi kedua variabel dimana variabel lainnya yang dianggap berpengaruh dikendalikan atau dibuat tetap (sebagai variabel kontrol). Karena variabel yang diteliti adalah data interval maka teknik statistik yang digunakan adalah Pearson Correlation Product Moment (Sugiyono, 2011). Menurut (Sugiyono, 2011) penentuan koefisien korelasi dengan menggunakan metode analisis korelasi Pearson Product Moment dengan menggunakan rumus sebagai berikut :

$$
\begin{aligned}
& r_{x y} \\
& =\frac{n \sum x i y i-\left(\sum x i\right)\left(\sum y i\right)}{\sqrt{\left\{n \sum x i^{2}-\left(\sum x i\right)^{2}\right\}}-\left\{n \sum y i^{2}-\left(\sum y i\right)^{2}\right\}}
\end{aligned}
$$

Keterangan :

$r x y=$ Koefisien korelasi pearson

$x i=$ Variabel independen

$y i=$ Variabel dependen

$n=$ Banyak sampel

Dari hasil yang diperoleh dengan rumus di atas, dapat diketahui tingkat pengaruh variabel $\mathrm{X}$ dan variabel $Y$. Pada hakikatnya nilai $r$ dapat bervariasi dari -1 hingga +1 , atau secara matematis dapat ditulis menjadi $-1 \leq \mathrm{r} \leq+1$. Hasil dari perhitungan akan memberikan tiga alternatif, yaitu: 1. Bila $\mathrm{r}=0$ atau mendekati 0 , maka korelasi antar kedua variabel sangat lemah atau tidak terdapat hubungan antara variabel $\mathrm{X}$ terhadap variabel $\mathrm{Y}$.

2. Bila $r=+1$ atau mendekati +1 , maka korelasi antar kedua variabel adalah kuat dan searah, dikatakan positif.

3. Bila $\mathrm{r}=-1$ atau mendekati -1 , maka korelasi antar kedua variabel adalah kuat dan berlawanan arah, dikatakan negatif.

Setelah mengetahui korelasi antara variabel $\mathrm{X}$ dan variabel $\mathrm{Y}$ maka kita perlu menghitung hubungan secara linear dengan rumus :

Keterangan :

$$
\mathrm{Y}=\mathrm{a}+\mathrm{bY}
$$

Y $\quad=$ Variabel dependent

a $\quad=$ Bagian Konstanta

$\mathrm{b} \quad=$ Koefisien arah regresi

Persamaan regresi dapat ditemukan dengan terlebih dahulu harus menghitung harga a dan harga $b$. cara menghitung harga a dan harga b dapat dihitung sebagaiberikut.

$$
a=\frac{n(\Sigma Y)\left(\Sigma X^{2}\right)-(\Sigma X)(\Sigma X Y)}{n \Sigma X^{2}-\left(\Sigma X^{2}\right)}
$$

$$
b=\frac{n \Sigma X Y-(\Sigma X)(\Sigma Y)}{n \Sigma X^{2}-(\Sigma X)^{2}}
$$

2014:272)

Keterangan:

Y : Variabel dependen

(Sekaran, 
X : Variabel independen

a : Bilangan konstan

b : Koefisien arah garis regresi

n : Lamanya periode

$\mathrm{X}$ dianggap mempengaruhi $\mathrm{Y}$, jika nilai $\mathrm{X}$ berubah maka nilai $\mathrm{Y}$ juga mengalami perubahan/ namun perubahan yang terjadi pada nilai $\mathrm{Y}$ tidak semata-mata disebabkan oleh $\mathrm{X}$ karena $\mathrm{X}$ hanya salah satu faktor yang menyebabkan perubahan pada nilai $\mathrm{Y}$ dan masih ada faktor lain yang menyebabkannya.

\section{Koefisien Determinasi}

Uji pengaruh yang digunakan adalah koefisien determinasi namun terlebih dahulu dilakukan perhitungan koefisien korelasi karena pada perhitungan koefisien korelasi membutuhkan nilai koefisien korelasi pearson. Menurut (Sugiyono, 2011) penentuan koefisien korelasi dengan menggunakan metode analisis korelasi Pearson Product Moment dengan menggunakan rumus sebagai berikut :

$$
\begin{array}{ll}
r_{x y} & \multicolumn{1}{c}{\frac{n x i y i-\left(\sum x i\right)\left(\sum y i\right)}{\sqrt{\left\{n \sum x i^{2}-\left(\sum x i\right)^{2}\right\}}-\left\{n \sum y i^{2}-\left(\sum y i\right)^{2}\right\}}} \\
& \text { Keterangan }: \\
& r x y=\text { Koefisien korelasi pearson } \\
& x i=\text { Variabel independen } \\
& y i=\text { Variabel dependen } \\
& n=\text { Banyak sampel }
\end{array}
$$

Untuk melihat seberapa besar tingkat pengaruh variabel independen terhadap variabel dependen secara parsial digunakan koefisien determinasi. Koefisien determinasi merupakan kuadrat dari koefisien korelasi sebagai ukuran untuk mengetahui kemampuan dari masing-masing variabel yang digunakan. Koefisien determinasi menjelaskan proporsi variasi dalam variabel dependen (Y) yang dijelaskan oleh hanya satu variabel independen secara bersama-sama.

Sementara itu $\mathrm{R}$ adalah koefisien korelasi majemuk yang mengukur tingkat hubungan antara variabel dependen (Y) dengan semua variabel independen yang menjelaskan secara bersamasama dan nilainya selalu positif. Selanjutnya untuk melakukan pengujian koefisien determinasi (adjusted R2 ) digunakan untuk mengukur proporsi atau presentase sumbangan variabel independen yang diteliti terhadap variasi naik turunnya variabel dependen. Koefisien determinan berkisar antara nol sampai dengan satu $(0 \leq \mathrm{R} 2 \leq 1)$. Hal ini berarti bila $\mathrm{R} 2=0$ menunjukkan tidak adanya pengaruh antara variabel independen terhadap variabel dependen, bila adjusted R2 semakin besar mendekati 1 menunjukkan semakin kuatnya pengaruh variabel independen terhadap variabel dependen dan bila adjusted R2 semakin kecil bahkan mendekati nol, maka dapat dikatakan semakin kecil pula pengaruh variabel independen terhadap variabel dependen. Rumus koefisien determinasi adalah sebagai berikut:

$$
K \mathrm{D}=\mathrm{r}^{2} X 100 \%
$$

Keterangan:

$K \mathrm{D}=$ Besar atau jumlah koefisien determinasi

$\mathrm{r}^{2}=$ Nilai koefisien korelasi

Sedangkan kriteria dalam melakukan analisis koefisien determinasi adalah sebagai berikut:

a. Jika Kd mendekati nol (0), berarti pengaruh variabel independen terhadap variabel dependen lemah, dan

b. Jika Kd mendekati satu (1), berarti pengaruh variabel independen terhadap variabel dependen kuat.

Untuk menafsirkan sejauh mana pengaruh antara lingkungan kewirausahaan terhadap motivasi berwirausaha maka digunakan pedoman interpretassi koefisien tertentu. Nilai koefisien penentu berada diantara $0-100 \%$. Jika koefisien semakin mendekati $100 \%$ berarti semakin kuat pengaruh variabel eksogen terhadap variabel endogen. Semakin mendekati 0\% maka semakin lemah pengaruh variabel eksogen terhadap variabel endogen sehingga dibuat pedoman interprestasi koefisien dalam tabel 2 sebagai berikut :

Tabel 2. Pedoman Untuk Memberikan Interprestasi Koefisiensi Determinasi

\begin{tabular}{cc}
\hline Interval Koefisiensi & Tingkat pengaruh \\
\hline $0-19,99 \%$ & Sangat Lemah \\
$20 \%-39,99 \%$ & Lemah \\
$40 \%-59,99 \%$ & Sedang \\
$60 \%-79,99 \%$ & Kuat \\
\hline
\end{tabular}


Sumber : (Sekaran, 2011)

\section{HASIL PENELITIAN DAN PEMBAHASAN}

Manurut Toutain et al.,(2017) perlua adanya usaha sadar dari sekolah untuk menciptakan dan membentuk kegiatan-kegiatan yang membuat siswa aktif dalam berkegiatan wirausaha. Fasilitas penunjang wirausaha, pelatihan kewirausahaan, dukungan sekolah, role model, serta perizinan usaha disekolah menciptakan lingkungan kewirausahaan yang mendorong siswa untuk berwirausaha (Alain Fayolle, 2008; Gnyawali \& Fogel, 1994; Yao, 2016).

Kemampuan pedagogik seorang guru ikut berperan dalam keberhasilan proses belajar mengajar di dalam maupun diluar kelas. Guru hendaknya menjadi panutan dan teladan serta pendorong siswa dalam proses pembelajaran kewirausahaan. Peningkatan kemampuan pedagogik guru melalui berbagai macam pelatihan sangat diperlukan untuk menunjang keberhasilan proses belajar mengajar (Purwanto, 2017; Syah, 2010)

Salah satu aspek kompetensi yang penting bagi seorang wirausaha ialah kemampuan untuk mewujudkan sesuatu. Seseorang dengan keyakinan kendali nternal (internal control), percaya bahwa sebagian besar kehidupan dan bisnisnya dikendalikan oleh dirinya sendiri. Dengan keyakinan besar bahwa hal-hal penting ada dibawah kontrolnya, seorang wirausaha wajib tahu kapan dan dengan siapa ia harus menerima dan membagi lntrol dalam hal-hal tertentu dengan pihak lain (Utomo, 2007).

Seseorang yang kuat hasrat berprestasi tampakmya berpeluang besar untuk menjadu wirausaha sukses. Keinginan untuk mengerjakan sesuatu dengan lebih baik dimasa depan dibandingkan masa lalu (Utomo, 2007) Self realization ( realisasi diri ) yaitu bagaimana individu merealisasikan dirinya. Realisasi diri tersebut bermakna bahwa individu akan selalu termotivasi apabila dirinya hidup dalam suatu cara yang sesuai dengan peran yang lebih disukai, diperlakukan sesuai dengan tingkatan yang lebih disukai dan dihargai sesuai dengan cara yang mencerminkan penghargaan seseorang terhadap kemampuannya (Pugacheva et al., 2016)

Bebas mengatur waktu, bebas dari aturan yang menekan dan bebas dari aturan budaya organisasi. Sekolah perlu mendukung siswa agar dapat hidup bebas namun sesuai dengan aturan yang berlaku, kebebasan dalam memilih cita-cita, kebebasan dalam menuangkan ide, kebebasan dalam berpendapat, dll. Namun, kebebasan tersebut masih perlu menjadi perhatian sekolah, misalnya dengan dibuat peraturan tata tertib disekolah yang bersifat tertib namun tidak mengekang siswa dalam mengembangkan dirinya (A Fayolle, Kyro, \& Liñán, 2015).

\section{Uji Asumsi Klasik terhadap Model Regresi Linier Sederhana}

Sebelum melakukan evaluasi terhadap model pengukuran dalam regresi linear sederhana mengenai pengaruh lingkungan kewirausahaan terhadap motivasi berwirausaha, perlu dilakukan uji asumsi klasik yang dilakukan dalam penelitian ini.

1. Uji Normalitas

Uji normalitas dilakukan untuk melihat apakah data hasil penelitian berdistribusi normal atau tidak. Uji normalitas dilakukan dengan menggunakan SPSS (Statistical Product and Service) 22.0 for windows. Sebagaimana Kolmogorov Smirnov Test, jika signifikansi di bawah 0,05 berarti terdapat perbedaan yang signifikan, dan jika signifikansi di atas 0,05 maka tidak terjadi perbedaan yang signifikan. Penerapan pada Kolmogorov Smirnov Test adalah bahwa jika signifikansi dibawah 0,05 berarti data yang akan diuji mempunyai perbedaan yang signifikan dengan data normal baku, berarti data tersebut tidak normal. Output uji normalitas ini dapat dilihat pada Tabel 3 berikut ini.

\section{Tabel 3. Uji Kolmogorov Smirnov}




\begin{tabular}{llr}
\hline \multicolumn{2}{c}{ One-Sample Kolmogorov-Smirnov Test } \\
\hline $\mathrm{N}$ & \multicolumn{2}{c}{ Unstandardized Residual } \\
Normal Parametersa,b & Mean & 167 \\
& Std. & .0000000 \\
& Deviation & 7.87783235 \\
Most Extreme Differences & Absolute & .034 \\
& Positive & .034 \\
& Negative & -.022 \\
Test Statistic & & .034 \\
Asymp. Sig. (2-tailed) & $.200^{c, d}$ \\
\hline a. Test distribution is Normal. \\
b. Calculated from data. \\
c. Lilliefors Significance Correction.
\end{tabular}

Sumber: Lampiran melalui SPSS 24.0 for windows 2018

Berdasarkan Tabel 2 diketahui tingkat signifikan sebesar 0,200 atau lebih besar dari 0,05 sehingga dapat dikatakan bahwa data berdistribusi normal. Selain itu uji normalitas juga menghasilkan gambar grafik Kolmogorov Smirnov Test. Output uji normalitas ini dapat dilihat pada gambar berikut ini.

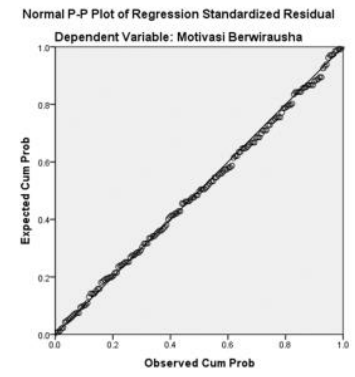

Sumber : Lampiran

\section{Gambar 2 .Output Uji Normalitas Lingkungan Kewirausahaan Terhadap Motivasi Berwirausaha}

Pada Gambar 2 tersebut menunjukkan bahwa data menyebar sekitar garis diagonal dan mengikuti arah diagonal. Maka regresi tersebut dapat disimpulkan populasi memenuhi asumsi berdistribusi normal. Suatu data akan berdistribusi secara normal jika nilai probabilitas yang diharapkan adalah sama dengan nilai probabilitas pengamatan dan kriteria data dapat dikatakan normal. Pada grafik Plots, kesamaan antara nilai porbabilitas harapan dan probabilitas pengamatan ditunjukan dengan garis diagonal yang merupakan perpotongan antara garis probabilitas harapan dan probabilitas diagonal (Sanusi, 2013).
Pengujian normalitas menggunakan Kolmogorov Smirnov Test menunjukkan bahwa data menyebar sekitar garis diagonal dan mengikuti arah diagonal. Maka regresi tersebut dapat disimpulkan bahwa populasi memenuhi asumsi berdistribusi normal. Selain itu untuk lebih memperkuat bukti bahwa data hasil penelitian berdistribusi normal atau tidak, maka peneliti melakukan pengujian normalitas menggunakan Kolmogorov-Smirnov Test.

\section{Uji Linearitas}

Setelah diketahui bahwa variabel lingkungan kewirausahaan terhadap motivasi berwirausaha berdistribusi normal, maka selanjutnya perlu diketahui apakah kedua variabel tersebut benarbenar memiliki hubungan linear, untuk itu perlu dilakukan uji lineritas regresi variabel $\mathrm{X}$ atas variabel Y. Pengujian lineritas ini dimaksudkan untuk mengetahui kemungkinan adanya hubungan linear antara lingkungan kewirausahaan terhadap motivasi berwirausaha. Hasil analisis data diperoleh output Anova pada Tabel 4 sebagai berikut.



Berdasarkan hasil pengujian linearitas diketahhui nilai Sig. deviation from linearity sebesar 0.064 atau lebih besar dari 0.05 artinya variabel lingkungan kewirausahan (X) secara keseluruhan model tersebut sudah fit dan terdapat hubungan antara variabel lingkungan kewirausahaan terhadap motivasi berwirausaha, sehingga regresi bisa dipakai untuk memprediksi lingkungan kewirausahaan. Berdasarkan hasil pengujian linearitas, maka dapat dikatakan bahwa data yang dihasilkan memenuhi asumsi linearitas. Pengujian linieritas dengan rumus berikut:

$$
\mathrm{F}=\frac{R^{2}(n-m-1)}{m\left(1-R^{2}\right.}
$$


Ket:

$\mathrm{n}=$ banyak anggota sampel (responden)

$\mathrm{m}=$ banyak prediktor

$\mathrm{R}=$ Korelasi

\section{Diagram Pencar}

Diagram pencar atau diagram serak (scatter plot) digunakan untuk mengetahui dan menunjukan ada tidaknya hubungan antara variabel $\mathrm{X}$ dan $\mathrm{Y}$ melalui penggambaran nilai dari variabel-variabel tersebut. Hasil pengolahan data pada SPSS (Statistical Product and Service Solution) 22.0 for windows.disajikan pada Gambar 4.6 sebagai berikut.

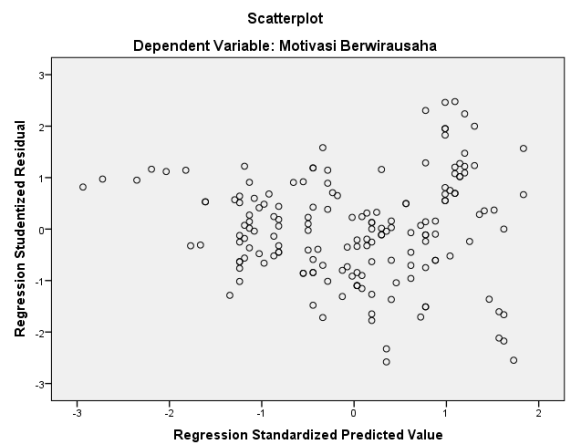

Sumber : Hasil pengolahan Data 2018

\section{Gambar 3 . Diagram Pencar Lingkungan Kewirausahaan Terhadap| Motivasi Berwirausaha}

Pada Gambar 3 menggambarkan bahwa titiktitik pada diagram pencar di atas menyebar berbentuk pola dari kiri bawah menuju kanan. Dari garis tersebut dapat diketahui kovaransi antara $X$ dan Y sifatnya searah, dalam arti bahwa apabila X berubah semakin besar maka $\mathrm{Y}$ pun berubah semakin besar, hal ini menunjukan bahwa ada hubungan antara variabel $\mathrm{X}$ dan $\mathrm{Y}$. Berdasarkan hasil uji asumsi klasik yang telah dilakukan, maka penelitian ini dapat diolah menggunakan analisis regresi liniear sederhana.

\section{Uji Titik Terpencil}

Setelah diketahui model diagram pencar dan telah menunjukkan pola garis lurus atau linear, langkah selanjutnya adalah memperhatikan titiktitik yang letaknya terpencil pada diagram pencar. Adapun output gambar uji titik terpencil lingkungan kewirausahaan terhadap motivasi berwirausaha dapat dilihat pada Gambar 4 berikut ini

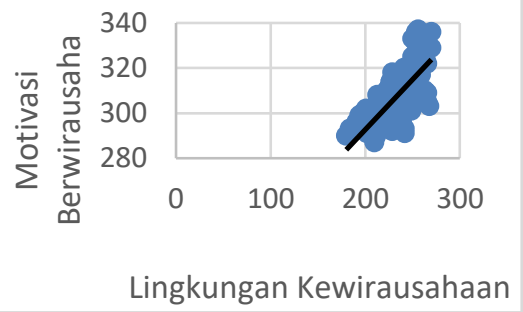

Sumber : Hasil pengolahan Data 2018

Gambar 4. Output Uji Titik Terpencil Lingkungan Kewirausahaan Terhadap Motivasi Berwirausaha

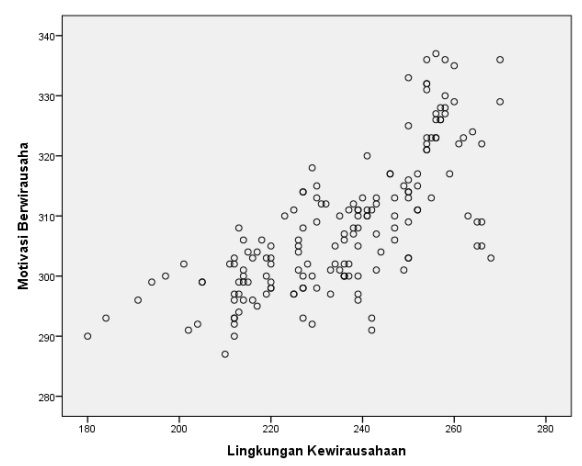

Sumber : Hasil pengolahan Data 2018

Gambar 5 . Output Uji Titik Terpencil Lingkungan Kewirausahaan Terhadap Motivasi Berwirausaha

Berdasarkan Gambar 5 tersebut, terdapat satu titik hitam yang dicurigai sebagai titik terpencil. Selanjutnya untuk mengetahui apakah titik hitam tersebut benar merupakan titik terpencil, maka dilakukan perhitungan dengan menggunakan rumus statistik uji. Dimana kriteria yang digunakan dalam uji ini yaitu:

$\mathrm{t}>t_{n-2}$ : Tolak $\mathrm{H}_{0}$, artinya titik yang mencurigakan dianggap sebagai titik terpencil dan harus dikeluarkan.

$\mathrm{t} \leq t_{n-2}$ : Terima $\mathrm{H}_{0}$, artinya titik yang mencurigakan tidak dianggap sebagai titik terpencil dan tidak perlu dikeluarkan dari analisis.

Pengujian statistik untuk mengetahui apakah titik hitam tersebut merupakan titik terpencil atau bukan, akan disajikan pada Tabel 4 berikut 
Tabel 4 . Uji Titik Terpencil

\begin{tabular}{|c|c|c|c|c|c|c|}
\hline$\dot{Y}$ & $\mathrm{x}$ & $Y=0,4851 x+16,791$ & 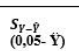 & 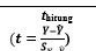 & $\begin{array}{l}t_{\text {tabel }} \\
(167-2)\end{array}$ & Ket \\
\hline 270 & 336 & $\mathrm{Y}=20$ & $\begin{array}{l}\begin{array}{l}0,055.336= \\
-335.95\end{array} \\
-\end{array}$ & $\begin{array}{l}t=\frac{17.171}{-335.95} \\
=-0.051\end{array}$ & 1,65141 & $\begin{array}{l}\text { Bukan } \\
\text { terpencil }\end{array}$ \\
\hline
\end{tabular}

Sumber : Pengolahan Data 2018

Berdasarkan hasil pengujian menggunakan $\mathrm{t}$ $\leq t_{n-2}$ didapatkan $t_{\text {hitung }}$ sebesar $-0,051$ sehingga $\mathrm{t}$ $\leq t_{n-2}$ atau $0,051<1,65141$. Berdasarkan Tabel 4.26 mengenai hasil pengujian titik terpencil, dapat diketahui bahwa" titik tersebut bukan merupakan titik terpencil, karena hasil thitung menunjukkan nilai yang lebih kecil daripada $t_{\text {tabel. }}$. Sehingga, kriteria yang digunakan atas hasil perhitungan tersebut adalah terima $\mathrm{H}_{0}$ yang artinya titik yang mencurigakan tidak dianggap sebagai titik terpencil dan tidak perlu dikeluarkan.

\section{Persamaan Regresi Linear Sederhana}

Model persamaan regresi sederhana yang akan dibentuk pada penelitian ini sebagai berikut.

$$
\mathrm{Y}=\mathrm{a}+\mathrm{bX}
$$

Sumber: Sugiyono (2013:247)

Keterangan:

$\mathrm{Y}=$ Variabel terikat (motivasi berwirausaha) $\mathrm{X}=$ Variabel bebas (lingkungan kewirausahaan)

a = harga $\mathrm{Y}$ bila $\mathrm{X}=0$ (harga konstan)

$\mathrm{b} \quad=$ Angka yang mempengaruhi peningkatan atau penurunan $\mathrm{Y}$ yang didasarkan oleh X (lingkungan kewirausahaan)

Dengan menggunakan program SPSS 22.0 for wondows, diperoleh hasil koefisien regresi sebagai berikut.

Tabel 6. Model Regresi Linear Sederhana

\begin{tabular}{|c|c|c|c|c|c|c|}
\hline \multicolumn{7}{|c|}{ Coefficients $^{\mathrm{a}}$} \\
\hline & \multirow[t]{2}{*}{ Model } & \multicolumn{2}{|c|}{$\begin{array}{l}\text { Unstandardized } \\
\text { Coefficients }\end{array}$} & \multirow{2}{*}{$\begin{array}{c}\text { Standardized } \\
\text { Coefficients } \\
\text { Beta }\end{array}$} & \multirow[t]{2}{*}{$\mathrm{t}$} & \multirow[t]{2}{*}{ Sig } \\
\hline & & B & Std. Error & & & \\
\hline \multirow[t]{2}{*}{1} & (Constant) & 203.651 & 7.677 & & 26.529 & .000 \\
\hline & $\begin{array}{l}\text { Lingkungan } \\
\text { Kewirausahaan }\end{array}$ & .445 & .033 & .729 & 13.686 & .064 \\
\hline
\end{tabular}

Berdasarkan Tabel 6 pada kolom B, tercantum nilai konstanta dan nilai koefisien regresi linear sederhana untuk variabel bebas. Berdasarkan nilai-nilai itu maka dapat ditentukan model regresi linear sederhana yang dinyatakan dalam bentuk persamaan sebagai berikut:

$$
\begin{aligned}
& Y=a+b X \\
& Y=203.651+0.445
\end{aligned}
$$

Berdasarkan persamaan regresi linier sederhana di atas, nilai konstanta sebesar 203.651 menyatakan bahwa jika tidak ada lingkungan kewirausahaan, maka besarnya motivasi berwirausaha sebesar 203.651. Koefisien regresi pada variabel lingkungan kewirausahaan adalah 0.445 yang artinya setiap terjadi penambahan nilai lingkungan kewirausahaan terjadi peningkatan motivasi berwirausaha sebesar 0.445 . Sebaliknya jika terjadi penurunan motivasi berwirausaha, lingkungan kewirausahaan akan menurunkan motivasi berwirausaha sebesar 0.445 satu satuan nilai.

Dapat dikatakan bahwa hubungan lingkungan kewirausahaan yang dibangun oleh sekolah akan berpengaruh terhadap tingkat motivasi berwirausaha . Jika hubungan lingkungan kewirausahaan kurang kondusif dengan siswa , maka akan menurunkan motivasi siswa disekolah untuk berwirausaha.

\section{Analisis Koefisien Determinasi}

Analisis koefisien determinan digunakan untuk mengetahui persentase pengaruh yang terjadi dari variabel bebas terhadap variabel terikat. Sehingga dalam penelitian ini koefisien determinan digunakan untuk mengetahui besarnya persentase pengaruh $\mathrm{X}$ terhadap $\mathrm{Y}$. Sehingga rumus yang digunakan adalah menurut Riduwan (2013:136), yaitu sebagai berikut:

$$
\mathrm{KD}=\mathrm{r}^{2} \times 100 \%
$$

Keterangan :

$r^{2}=$ koefisien korelasi

\begin{tabular}{|c|c|c|c|c|}
\hline \multicolumn{5}{|c|}{ Model Summary ${ }^{b}$} \\
\hline & & & Adjusted R & Std. Error of the \\
\hline Model & $\mathrm{R}$ & R Square & Square & Estimate \\
\hline 1 & $.729^{\mathrm{a}}$ & .532 & .529 & 7.902 \\
\hline \multicolumn{5}{|c|}{$\begin{array}{l}\text { a. Predictors: (Constant), Lingkungan Kewirausahaan } \\
\text { b. Dependent Variable: Motivasi Berwirausaha }\end{array}$} \\
\hline \multicolumn{5}{|c|}{ Sumber: Pengolahan data 2018 } \\
\hline
\end{tabular}

Tabel 7. Koefisien Determinasi Lingkungan Kewirasuahaan terhadap Motivasi Berwirausaha 
Sumber : Hasil Pengolahan Data 2018

Berikut adalah hasil perhitungan koefisien determinasi dari $\mathrm{X}$ terhadap $\mathrm{Y}$ :

$$
\begin{aligned}
& \mathrm{KD} \quad=\mathrm{r}^{2} \times 100 \% \\
& =\mathrm{r}^{2} \times 100 \% \\
& =(\mathbf{0 , 5 3 2})^{2} \times 100 \% \\
& =0,532 \times 100 \% \\
& =\mathbf{5 3 , 2 \%}
\end{aligned}
$$

Dari hasil penghitungan koefisien determinasi untuk lingkungan kewirausahaan (X) terhadap motivasi berwirausaha (Y) adalah 53,2\%, dengan kata lain motivasi berwirausaha cukup dipengaruhi $53,2 \%$ oleh lingkungan kewirausahaan.

\section{Uji Hipotesis Pengaruh Lingkungan} kewirausahaan berpengaruh terhadap Motivasi berwirausaha pada siswa kelas XII SMK Negeri 1 Cimahi

Untuk menguji signifikansi lingkungan kewirausahaan berpengaruh terhadap motivasi berwirausaha dapat digunakan uji t, yaitu dengan membandingkan antara $t_{\text {hitung }}$ dan $t_{\text {tabel }}$. Rumus uji $\mathrm{t}$ atau uji coefficients dijelaskan pada Tabel 8

\begin{tabular}{|c|c|c|c|c|c|c|}
\hline \multicolumn{7}{|c|}{ Coefficients $^{\mathrm{a}}$} \\
\hline \multirow{3}{*}{1} & \multirow[b]{2}{*}{$\begin{array}{l}\text { Model } \\
\text { (Constant) }\end{array}$} & \multicolumn{2}{|c|}{$\begin{array}{l}\text { Unstandardized } \\
\text { Coefficients }\end{array}$} & \multirow{2}{*}{$\begin{array}{c}\text { Standardized } \\
\text { Coefficients } \\
\text { Beta }\end{array}$} & \multirow[t]{2}{*}{$t$} & \multirow[b]{2}{*}{$\begin{array}{l}\text { Sig. } \\
.000\end{array}$} \\
\hline & & $\begin{array}{c}\text { B } \\
203.651\end{array}$ & $\begin{array}{c}\text { Std. Error } \\
7.677\end{array}$ & & & \\
\hline & $\begin{array}{c}\text { Lingkungan } \\
\text { Kewirausahaan }\end{array}$ & .445 & .033 & .729 & 13.686 & .000 \\
\hline
\end{tabular}
sebagailberikut.

Tabel 8. Nilai Signifikansi Uji t Lingkungan

Kewirausahaan Berpengaruh Terhadap Motivasi Berwirausaha

a. Dependent Variable: Motivasi Berwirausaha Sumber: Pengolahan data 2018

Sumber : Hasil Pengolahan Data 2018

Tabel 7 menunjukan pengujian untuk uji $\mathrm{t}$ yang diambil dari Coefficients dengan menggunakan uji t yaitu $t_{\text {hitung }}>t_{\text {tabel }}$. Maka $t_{\text {tabel }}$ dengan 167 responden yaitu pada $a=0,05$ adalah 1,65141. Sehingga didapat 13,686 >1,65141, maka $\mathrm{H}_{\mathrm{o}}$ ditolak. Kesimpulannya sama dengan pengujian yang dilakukan dengan menggunakan nilai probabilitas. Dengan demikian dapat disimpulkan bahwa hipotesis dalam penelitian ini yaitu $\mathrm{H}_{\mathrm{o}}$ ditolak dan $\mathrm{H}_{\mathrm{a}}$ diterima, sehingga terdapat pengaruh antara lingkungan kewirausahaan terhadap motivasi berwirausaha pada siswa kelas XII SMK Negeri 1 Cimahi.

Secara statistik, hipotesis yang diuji dalam rangka pengambilan keputusan penerimaan atau penolakan hipotesis dapat dirumuskan sebagai berikut:

H0 : $\rho \leq 0$, artinya tidak dapat pengaruh dari lingkungan kewirausahaan terhadap motivasi berwirausaha

Ha : $\rho>0$, artinya terdapat pengaruh positif dari lingkungan kewirausahaan terhadap motivasi berwirausaha.

Berdasarkan tabe 4.18 diketahui bahwa $\rho(R$ Square) adalah sebesar 0.532 atau $\rho>0$. Syarat agar $\mathrm{H}_{\mathrm{a}}$ diterima atau terdapat pengaruh antara lingkungan kewirausahaan terhadap motivasi berwirausaha adalah $\rho>0$. Dengan demikian dapat disimpulkan bahwa hipotesis dalam penelitian ini yaitu $\mathrm{H}_{\mathrm{o}}$ ditolak dan $\mathrm{H}_{\mathrm{a}}$ diterima, sehingga terdapat pengaruh antara lingkungan kewirausahaan terhadap motivasi berwirausaha pada siswa kelas XII SMK Negeri 1 Cimahi.

\section{KESIMPULAN DAN REKOMENDASI}

Hasil penelitian menyatakan jika lingkungan kewirausahaan berpengaruh terhadap motivasi berwirausaha siswa sebesar 53,2 \% dan sisanya $46.8 \%$ dipengeruhi oleh faktor yang tidak diteliti. Beberapa ahli lain mengemukaan faktor-faktor pendukung wirausaha. Budaya merupakan faktor lain yang dapat mempengaruhi motivasi berwirausaha yaitu (Aramand, 2013). Tingkat pengertian resiko dan entrepreneurial ambiguity mendorong seseorang untuk memahami peluang dan tantangan berwirausaha untuk meningkatkan motivasi berwirausaha (Ismail et al., 2016). Motif gaya hidup, menerima pengakuan, meningkatkan keuntungan dan kelangsungan keuangan merupakan faktor yang mempengaruhi motivasi berwirausaha (Boluk \& Mottiar, 2014). Tingginya tingkat pengangguran, kebutuhan akan penghargaan, kemandirian, kebebasan dalam memiliki usaha merupakan faktor pendorong motivasi berwirausaha (Soydas \& Aleti, 2015). 


\section{DAFTAR PUSTAKA}

Basrowi. (2011). kewirausahaan untuk Perguruan Tinggi. Bogor: Ghalia Indonesia.

Boluk, A. K., \& Mottiar, Z. (2014). Motivations of social entrepreneurs Blurring the social contribution and profits dichotomy, 10(1), 53-68. http://doi.org/10.1108/SEJ-01-2013-0001

Dehkordi, A. M., Sasani, A., Candidate, M. A., \& Management, E. (2012). Investigating the Effect of Emotional Intelligence and Personality Traits on Entrepreneurial Intention Using the Fuzzy DEMATEL Method University of Tehran, 3(13), 286-296.

Eijdenberg, E. L. (2016). Does one size fit all? A look at entrepreneurial motivation and entrepreneurial orientation in the informal economy of Tanzania, 22(6), 804-934. http://doi.org/10.1108/IJEBR12-2015-0295

Fayolle, A. (2008). Linking entrepreneurial orientation and dynamic capabilities: research issues and alternative models. The Dynamics between Entrepreneurship, Environment and Education, 308. http://doi.org/10.1017/CBO9781107415324.004

Fayolle, A., Kyro, P., \& Liñán, F. (2015). Developing, shaping and growing entrepreneurship. Developing, Shaping and Growing Entrepreneurship. http://doi.org/10.4337/9781784713584

Fereidouni, H. G., Masron, T. A., \& Nikbin, D. (2010). CONSEQUENCES OF EXTERNAL ENVIRONMENT ON, 15(2), 175-196.

Gnyawali, D., \& Fogel, D. (1994). Environments for Entrepreneurship Development : Key Dimensions and Research Implications, (March). http://doi.org/1042258794184

Ismail, I., Husin, N., Abdul, N. M., Hanum, M., \& Che, R. (2016). Entrepreneurial Success among Single Mothers: The Role of Motivation and Passion. Procedia Economics and Finance, 37(16), 121$128 . \quad$ http://doi.org/10.1016/S22125671(16)30102-2

Kingdom, U., Orziemgbe, G., Chukwujioke, K., Aondoaver, T., \& Polytechnic, B. S. (2014). Relationship Between Emotional Intelligence And Entrepreneurial Performance: The Mediating, II(10), 1-16.

Knight, J. (2015). The evolving motivations of ethnic entrepreneurs. Enterprising Communities, 9(2), 114-131. http://doi.org/10.1108/JEC-10-20130031

Koranti, K. (2013). ANALISIS PENGARUH FAKTOR
EKSTERNAL DAN INTERNAL, 5(1998), 8-9.

Mitra, J. (2013). Entrepreneurship, Innovation and Regional Development (1st ed.). New York: Routledge.

Mulyadi, H. (2010). Pengaruh Pendidikan dan Latihan Terhadap sikap kewirausahaan serta Implikasinya pada Perilaku kewiraushaaan Mahasiswa.

Mulyadi, H., \& Irawan, A. (2016). Pengaruh Keterampilan Wirausaha Terhadap Keberhasilan Usaha, 1(1), 213-223.

Nafziger, E. W. (2012). Economic Development (Fourth i). New York: Cambridge University Press.

Nuryanti, b lena. (2004). Model Pembelajaran ELearning Melalui Homepage Sebagai Media Pembelajaran Sehingga Diharapkan Dapat Meningkatkan Minat Dan Kreativitas Siswa. Model Pembelajaran E-Learning Melalui Homepage Sebagai Media Pembelajaran Sehingga Diharapkan Dapat Meningkatkan Minat Dan Kreativitas Siswa, 1(1), 7.

Olvecka, V. (2013). DEVELOPMENT OF ENTREPRENEURIAL ENVIRONMENT IN SLOVAKIA, $\quad 7(2), \quad 216-229$. http://doi.org/10.13165/IE-13-7-2-06

Pugacheva, N. B., Ezhov, S. G., Kozhanov, I. V, Kozhanova, M. B., Ogorodnikova, S. V, Oshaev, A. G., ... Goloshumova, G. S. (2016). The Model of Self-realization Readiness Formation of Research Universities Students in the Process of Civic Education, 6(1), 128-133.

Purwanto, N. (2017). PSIKOLOGI PENDIDIKAN (28th ed.). Bandung: Remaja Rosdakarya.

Riduwan. (2013). Belajar Mudah Penelitian. Bandung: Alfabeta.

Rusdiana. (2014). Kewirausahaan Teori dan Praktek (1st ed., Vol. 52). Jakarta: Pustaka Setia. Retrieved from http://search.proquest.com/docview/1651837258 ?accountid $=14548$

Sanusi, A. (2013). Metodologi Penelitian Bisnis (cetakan ke). Jakarta: Salemba empat.

Sarmento, M. F. P. G. M. (2016). Predicting entrepreneurial motivation among university students : The role of entrepreneurship education, 58(7/8). http://doi.org/http://dx.doi.org/10.1108/ET-012016-0019

Shetzer, L., Stackman, R. W., \& Moore, L. F. (2010). Business-Environment Attitudes and the New Environmental Paradigm, (March 2015), 37-41. http://doi.org/10.1080/00958964.1991.9943057

Siagian, S. \&. (2006). Metode Statistika Untuk Bisnis 
dan Ekonomi. Jakarta: PT Gramedia Pustaka Utama.

Sitepu SK, N. (1994). Analisis Korelasi dan Regresi. Bandung: Unit Pelayanan Statistika UNPAD.

Sugiyono. (2011). Metode Penelitian Pendidikan (Pendekatan Kuantitatif, Kualitatif, dan R\&D). Bandung: Alfabeta.

Sugiyono. (2014). Metode Penelitian Kuantitatif, Kualitatif, dan R\&D. Bandung: Alfabeta.

Syah, M. (2010). Psikologi Pendidikan dengan pendekatan baru. Bandung: Remaja Rosdakarya.

Toutain, O., Fayolle, A., Pittaway, L., \& Politis, D. (2017). Role and impact of the environment on entrepreneurial learning. Entrepreneurship and Regional Development, 29(9-10), 869-888. http://doi.org/10.1080/08985626.2017.1376517

Utomo, D. (2007). Menjadi Entrepreneur Jempolan. Jakarta: Replubika.

Yao, X. (2016). Effect of students , perceived entrepreneurial environment, $8(1)$ http://doi.org/http://dx.doi.org/10.1108/JEEE-032015-0021 